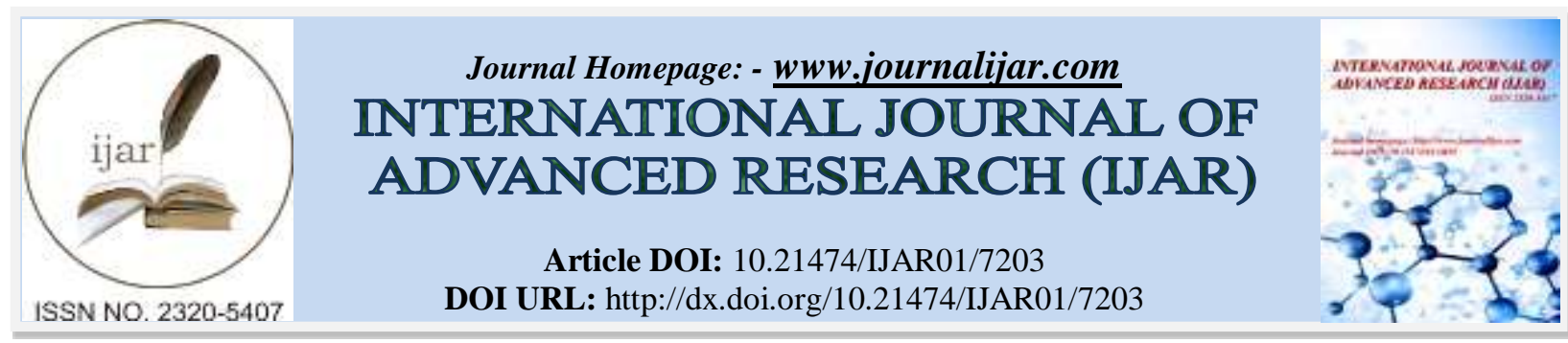

RESEARCH ARTICLE

\title{
LEGAL STATUS OF MARITAL TREASURE IN THE FORM OF MONEY SAVING IN BANK.
}

\section{Dyah Auliah Rachma Ruslan ${ }^{1}$, Anwar Borahima ${ }^{2}$ and Nurfaidah Said ${ }^{2}$.}

1. Graduate School, Faculty of Law, Hasanuddin University.

2. Faculty of Law, Hasanuddin University.

\section{Manuscript Info}

Manuscript History

Received: 04 April 2018

Final Accepted: 06 May 2018

Published: June 2018

Keywords:-

Legal Actions, Legal Status, Marital

Treasure, Saving of Money In Bank.

\begin{abstract}
The reason the bank didn't request the consent of the husband/wife of the depositing customer in the case of withdrawal/transfer of deposits which is joint treasure in the bank is not in accordance with the provisions of Article 36 Paragraph (1) of the Marriage Law and Article 92 of the Compilation of Islamic Law which requires the existence of a husband consent and wife in the conduct of legal actions related to joint property, the reason the bank doesn't ask permission from the husband/wife of the depositing customer in the case of withdrawal or transfer of the savings on the grounds that the bank will find it difficult to determine whether the deposit is a common property or insufficient property, basically in accordance with the provisions of Article 5 of Bank Indonesia Regulation concerning Know Your Customer Principles, the bank is required to inquire about the source of funds from the depositors' deposits. Basically there is no form of protection provided by the bank to the husbands or wives of depositors who are joint treasures in the bank, in which case the bank has never sought the consent of the spouse's husband or wife in the case of withdrawal or transfer of deposits at the bank, but at the whim of customers and their spouses may then create a joint account and may also make a written statement to draw up the withdrawal or transfer of deposits constituting such joint property.
\end{abstract}

Copy Right, IJAR, 2018,. All rights reserved.

\section{Introduction:-}

Marriage is one of the most important legal events in the life of society. Marriage as a legal event is characterized by the inner birth bond between man and woman through the marriage contract or qabul's consent, which transforms the status of a man into a husband and a woman into a wife. Marriage which is held legitimately gives effect in the field of law that is the emergence of relationship between husband and wife, the emergence of the relationship between parents and children and the emergence of marital property. The consequences in the field of property with the occurrence of marriage is the existence of common property and luggage.

One form of joint treasure in marriage is the saving of money in the Bank, as long as a couple doesn't make a marriage agreement to separate the property acquired during the marriage takes place. The consequence of this is that all property acquired during marriage will be a common property as well as deposits in the form of money in a bank owned by a husband or wife after marriage takes place, which is not a savings earned by inheritance or prize. Therefore it can be concluded that deposits which are common property are deposits obtained after marriage as long 
as the deposits aren't obtained because of inheritance or gifts, other than that the husband or wife is not bound by the separation of property agreement.

Bank is an institution entrusted to collect funds from the public in the form of deposits, either in the form of savings deposits, current accounts or other similar forms. In practice, if the joint property between the husband or wife wants to be deposited in the bank then the bank will provide one account number for one name of the name of the husband or wife. A party whose name is registered as an account holder may access, retrieve and/or transfer the existing savings in the Bank, even though the deposits in the bank are jointly owned by the account holder and his/her spouse and although the owner of the savings with his/her spouse doesn't exist treasury separation agreement. ${ }^{1}$ This provides enormous powers to those whose names are registered as owners of such deposits which make it seem as though the deposits aren't mutual treasures. This may cause problems because parties whose names aren't registered as savings or savings holders in the Bank may lose their right to know the joint property in the account, while the registered party in the bank account may freely access, transfer and retrieve the deposit without the consent of her partner. This is certainly not in line with Article 36 Paragraph (1) of Law Number 1 Year 1974 concerning Marriage (hereinafter referred to as marriage law) stipulating that the joint property, husband or wife can act upon the agreement of both parties.

In practice, the banks don't seek approval from the parties of their clients in the case of taking or transferring a number of funds that are mutual property. This is different from the process of taking credit in banks that require the need for permission from the spouses of credit applicants if the husband and wife there is no marriage agreement. According to information from the bank that the author obtained the reason of the bank to ask permission from the husband/wife partner of the applicant credit because it is one form of risk mitigation from the bank. ${ }^{2}$

Article 35 paragraph (1) of the Marriage Law stipulates that property acquired during marriage becomes common property, the property intended in this case is not only in the form of assets but also in the form of liabilities, therefore according to the bank also required the permission of the husband/wives of credit applicants because it will have an impact on their household finances. Unlike the case of credit applications requiring the consent of a spouse for those who don't enter into a property separation agreement, in the case of withdrawal or transfer of a certain amount of funds in the form of money deposits in the bank doesn't require the consent of the spouses even though such deposits include joint property.

Another problem that can arise related to joint property in the form of money deposits in the bank is when the marriage breakdown between depositors with their husbands/wives, especially in the case of marriage broke up because of divorce. This is because in the account only one person whose name is registered as the owner of the savings, so the spouse of the depositary customer can't access the joint property in the form of deposits in the bank. This of course can make spouses lose their rights to deposits in banks which is a joint treasure.

\section{Method of the Research:-}

The type of research used in the writing of this thesis is normative legal research. Normative law research uses normative case studies of legal behavioral products, such as reviewing laws. The subject of the study is that the law is conceptualized as the norm or rule that prevails in society and becomes the reference of everyone's behavior, so that normative legal research focuses on the inventory of positive law, legal principles and doctrines, legal discovery in concreto, systematic law, synchronization level, comparative law and legal history. ${ }^{3}$

The types and sources of legal materials used in the writing of this thesis are primary legal materials and secondary legal materials. The primary legal materials are legal materials that have binding legal force, namely the Marriage Law, the Banking Act, the Compilation of Islamic Laws, the Laws of the Financial Services Authority, the Laws of Bank Indonesia, the Regulations of Bank Indonesia, the Regulations of the Authorities Financial Services and Decisions of the Constitutional Court Number 64/PUU-X/2012. Whereas secondary law material is the material that gives explanation about primary law material namely law books concerning banking law, marriage law and other books related to this writing, the result of writing relevant to this research including journal of law; and the opinions of related legal experts.

\footnotetext{
${ }^{1}$ Pre-Research Results Conducted at Bank Rakyat Indonesia Makassar Branch On February 8, 2018.

${ }^{2}$ Pre-Research Results Conducted at Bank Rakyat Indonesia Makassar Branch On February 8, 2018.

${ }^{3}$ Abdulkadir Muhammad. 2004. Hukum dan Penelitian Hukum. Cet. 1. Bandung: PT. Citra Aditya Bakti. p. 52.
} 
The technique of collecting materials used in this writing is done by library research. The material obtained in the research in the form of primary legal materials and secondary legal materials, analyzed qualitatively and then presented descriptively, that is by describing, explaining, and describing the authority of husband and wife to the joint property in the form of deposits in the Bank and the protection of the husband/wife depositor saving of money in a bank which is a common property.

\section{Results and Discussion:- \\ Reasons Banks Don't Ask for Permission from Husband/Wife of the Customer in the Withdrawal or Transfer of Deposits that Represent Joint Treasure in Bank}

The banking institution is the core of the financial system of each country. The Bank is a financial institution that becomes the place of individual private business entities, state-owned enterprises, and even government agencies keep their funds. Through credit activities and various services provided, banks serve the financing needs as well as launch a payment system mechanism for all sectors of the economy. ${ }^{4}$ G. M. Verryn Stuart states that a bank is a body that aims to satisfy credit needs, either with its own means of payment or with money derived from others, or by circulating new exchange instruments in the form of demand deposit..$^{5}$

Article 3 of the Law on Banking determines that the main function of Indonesian banking is to collect and channel public funds. From this provision is reflected the function of banks as an intermediary parties who have surplus of funds with the parties who lack and require funds. This function will work if the seller and the purchaser of goods and services believe that the instrument used for the payment will be received and paid by all parties in the transaction and the related transaction. Thus without the trust, the function will not work. ${ }^{6}$

Based on the results of the research authors, in the case of making a savings account in the bank either in the form of savings, deposits and giro which is a joint property is not required the consent of the husband/wife of depositors who are married and in the proof of ownership of the account listed as the account owner is only the depositors. Neither in the case of withdrawal or transfer of deposits is not required the consent of the married customer's husband/wife in the amount of any withdrawal or transfer transaction. Although savings in the form of savings, deposits and current accounts in the bank is a joint treasure between the account owner and his/her spouse.

Referring to the Marriage Law in Indonesia, of course talking about people who are married and who aren't bound by marriage there is a fundamental difference that is in terms of wealth properties. Marriage Law divides marital property into joint property and possessions, it affects the authority of one acts in performing legal acts related to the property in the marriage.

Article 36 Paragraph (2) of the Marriage Law stipulates that in respect of individual property, the husband and wife shall have the full right to engage in legal acts concerning their property, while Article 36 Paragraph (1) of the Marriage Law provides that on the common property, the husband or the wife may act upon the agreement of both parties. From the provision of Article 36 of this Marriage Law, it can be seen that in performing legal acts related to the property of each husband and wife can act independently, while for the joint property of husband and wife must act on the agreement of both. This provision is also in line with Article 92 of the Compilation of Islamic Law which prescribes that the spouse or husband without the consent of the other party is not allowed to sell or transfer the joint property.

According to Muhammad Auliyah, the reason the bank didn't ask the husband/wife permission from the depositors in the bank which is a joint property is in principle the savings are funds derived from the account owner who can only be managed by the account owner himself without any intervention from the bank. According to him, in this case the bank can't interfere in personal affairs between husband and wife, although the existing savings in the bank is a joint treasure. The Bank shall only assume that the owner of the deposit is the person whose name is registered as the account holder, even though the funds held are mutual property and between the spouses and the spouse there is no separation of property agreement. It is also related to the principle of secrecy held by the bank, where the bank

\footnotetext{
${ }^{4}$ Hermansyah. 2011. Hukum Perbankan Nasional Indonesia. Kencana Prenada Media Group : Jakarta. p. 7.

${ }^{5}$ Ibid. p. 8.

${ }^{6}$ Zulkarnain Sitompul. 2002. Perlindungan Nasabah Bank: Suatu Gagasan Tentang Pendirian Lembaga Penjamin Simpanan Di Indonesia. Fakultas Hukum, Universitas Indonesia : Jakarta. p. 1
} 
must maintain all confidentiality of customer data including deposits in the bank and all actions committed to the customer's savings in the bank. ${ }^{7}$

According to Nursidik, deposits are something that is personal, so the bank can't interfere and regulate all actions performed by the owner of the account, because the savings are private, the account holder can take and transfer the deposits in any amount without permission from the parties others included from their marriage partners, and although these deposits are common property. Each bank must apply the principle of confidentiality and the principle of trust, which means the bank must be able to keep all confidential data of depositors and banks as depositors entrusted by their clients must be able to maintain the trust of this account owner to keep and keep all information about the customer and deposits including any actions taken by the customer against his or her savings in the bank. ${ }^{8}$

According to Asdar, the bank is a financial intermediary whose function is to collect funds from the public, in accordance with the function of banks in the provisions of Article 3 of the Banking Act which determines that the main function of Indonesian banks is as collectors and distributors of public funds. As a financial intermediary the bank is merely an institution to deposit funds and there is no authority from the bank to regulate and limit the authority of the person whose name is registered as the account holder in the event of withdrawing or transferring his/her savings in the bank. In the sense that the bank doesn't require the permission of the other party either from the husband/wife of the depositing customer if the depositor wishes to withdraw or transfer any deposits in the bank in any amount, even in the opening of the bank account presenting the source of funds owned by the prospective customer, is intended to find out whether the fund is a joint property for prospective customers who are married. It is only to find out whether the source of the prospective customer's fund comes from salary, grant/inheritance, business results, investment returns and other activities performed by the prospective customer. In large-scale transactions of over Rp 100,000,000.00 (one hundred million rupiah) the bank will also ask for the source and purpose of the use of the funds, this is intended to prevent the crime of money laundering and terrorism financing, in addition the bank will report transactions to the Center for Financial Transaction Reporting and Analysis, this is also to prevent the crime of money laundering. ${ }^{9}$

According to Asdar, in terms of service to customers in accordance with Standard Operating Procedures the bank also recognizes the principle of service excellence. Service Excellent is a service that meets quality standards in accordance with customer expectations and satisfaction, based on the principle of service excellent the bank must provide speed and ease in service for each customer, because to take or transfer deposits in the bank only the approval of the account owner only and not requires the consent of the spouse of the account holder. This is to provide convenience to its customers in conducting transactions in the bank.

According to Asdar, the deposit of money in a bank constitutes a depositary agreement between a bank as a depositary and a customer as a depositor, in this case the customer is the only person registered in the account, therefore all acts concerning such deposits may only be done by the owner of the savings without any intervention from the bank, other than that based on the deposit of funding the bank as a depository institution is obliged to keep all information about the owner of the savings, so that all acts either withdrawal or transfer of deposits can't be notified to other parties including husband/the wife of the customer, even though the deposit is a joint treasure. ${ }^{10}$

According to Muhammad Auliyah, one of the reasons the bank didn't ask the consent of the husband/wife of the depositor in the case of withdrawal or transfer of money in the bank is the difficulties of the bank to determine whether the source of funds is a common property, because basically appropriate with Standard Operating Procedure of depositing in the bank of any deposit of money in the bank, the bank doesn't ask whether the property is a shared treasure or the property of the depository customer. In addition, the bank will also be difficult in terms of determining when the start of the deposit is calculated into joint property, because at the time of opening of the bank

\footnotetext{
${ }^{7}$ Interview with Muhammad Auliyah as staff of Legal Bank Rakyat Indonesia Makassar Branch on March $10,2018$.

${ }^{8}$ Interview with Nursidik as Legal staff of Bank Mega Makassar Branch on March 23, 2018.

${ }^{9}$ Interview with Asdar as staff of Legal Bank Tabungan Negara Branch Makassar on March 18, 2018.

${ }^{10}$ Interview with Asdar as staff of Legal Bank Tabungan Negara Branch Makassar on March 18, 2018.
} 
account doesn't ask for documents in the form of marriage books from prospective customers and their husbands/wives. ${ }^{11}$

In my opinion as the writer, in this case the attitude of the bank that doesn't ask for the consent of the spouse's partner/husband in the bank where the deposit is a joint property and between husband and wife there is no agreement of separation of property not in accordance with the provisions of Article 36 paragraph (1) The Marriage Law which prescribes that the common property, husband or wife may act on the mutual agreement of the parties, and the provision of Article 92 of the Compilation of Islamic Law which prescribes that the spouse or husband without the consent of the other party is not allowed to sell or transfer the joint property.

I think as a writer, although in this case the bank is only a financial intermediary which is only an institution to deposit funds, but the bank should also pay attention to the provisions of Article 36 Paragraph (1) of the Marriage Law and Article 92 of the Compilation of Islamic Law. This is because even though only one name is registered as the owner of the account, but in the deposit there is also the right of the other party, the husband/wife of the depositor. Therefore, it is appropriate that the bank also involves the spouse of the depositary customer in the case of withdrawal or transfer of savings in the form of money in the bank which is a joint treasure.

I think as a writer, although in this case the bank considers that the deposit is the personal affairs of the husband and wife, but as a financial institution where to keep the funds entrusted by the community, the bank should also pay attention to the interests of others regarding deposits in the the bank. It is also related to the prudential principles that should be applied by each bank, so to anticipate the objections of the spouses of the depositing customers in the future, the bank should also involve the spouse of the depositary customer in the case of withdrawal/transfer of savings in the form money in a bank which is a joint treasure.

If it refers to the provisions of Article 35 of the Marriage Law, savings that can be categorized as joint property shall be deposits obtained during marriage which aren't derived from inheritance or prizes, this provision is valid as long as the husband and wife don't specify otherwise in the marriage agreement. According to the authors the reason bank didn't ask permission from the husband/wife of the depositing customer in the case of withdrawal or transfer of the savings on the grounds that the party will find it difficult to determine whether the savings are mutual property or insufficient property, because basically in accordance with the provisions of Article 5 Regulation Bank Indonesia on Know Your Customer Principles of the bank is required to inquire about the source of funds from the depositors' deposits, but this is only intended to avoid the existence of money laundering. It should be in this case the question of the source of funds is not only intended for the prevention of money laundering crime but also can be made access by the bank in determining whether the deposit is a joint property, moreover the bank also asked the marital status of a depositary customer at the time account opening.

Although there is currently no regulation requiring the bank to seek the approval of the spouse in the withdrawal or transfer of money in the bank which is a joint property, but the bank as a public funding institution should not only be bound by banking rules but also are bound in the provisions of Article 36 Paragraph (1) of the Marriage Law and Article 92 of the Compilation of Islamic Law. In addition, in accordance with the provisions of Article 1 paragraph 3 of the Constitution of the Unitary State of the Republic of Indonesia Year 1945 which determines that Indonesia is a State of law, where one of the objectives of law is to provide justice for every citizen, therefore to provide justice should the bank may establish a regulation to observe the rights of the spouse of the depositary customer against the deposit in the bank which is the common property.

Legal Protection Provided by the Banking Party to the Husband/Wife of the Depositary in the Form of Money in the Bank Representing the Joint Marital Treasure

Marriage is a legal event that gives rise to legal consequences. Marriage by husband and wife will legitimately bring legal consequences. The effect of the law is the emergence of husband and wife relationship, the emergence of parent and child relationship and the emergence of joint property. Article 35 paragraph (2) of the Marriage Law prescribes that property is the property of each husband and wife and property obtained respectively as a gift or inheritance as long as the parties don't specify otherwise. Article 87 Paragraph (1) The Compilation of Islamic Law determines that property is the property of each husband and wife and the property acquired respectively as a gift or

\footnotetext{
${ }^{11}$ Results of interview with Mr. Muhammad Auliyah as staff of Legal Bank Rakyat Indonesia Makassar Branch on
} March 10, 2018. 
inheritance as long as the parties don't specify otherwise in the marriage agreement. The collective treasury doesn't distinguish the origin of who produces it, meaning the treasure of any of those who produce it or on behalf of any one of them, provided that the property is acquired during the marriage period, the property is included in the common property. ${ }^{12}$

According to Customer Service of Bank Rakyat Indonesia Makassar Branch, in practice if joint property between husband or wife wants to be stored in bank then bank will give one account number on behalf of one side that is name of husband or wife. From that point only the name of the party is used that can access, retrieve and/ or transfer the existing savings in the Bank, although the existing savings in the bank is a joint property and between the owner of the savings with his partner there is no agreement of separation of property. ${ }^{13}$

According to Muhammad Auliyah, until now there is no protection given to the husband/wife of depositors in the bank if the protection in question is the consent of the husband/wife of the customer if the customer wants to take or transfer the deposits that are the joint property. In the bank rules set forth in the Standard Operating Procedures of withdrawal or transfer of deposits in the bank, the bank doesn't require or require the consent of the husband/wife of the depositing customer if only one name is recorded in the account, and the wife wishes to do the bank authorizes the husband and wife to make a written statement regarding their wishes to the deposits in the bank which is the joint treasure. $^{14}$

According to Muhammad Auliyah, in the statement the married couple can determine their will according to the second agreement, so if the account is registered in the name of the husband then in the written statement the married couple may determine that in the case of withdrawal and transfer of savings requires the consent of the wife or husband. In the written statement, the husband and wife can determine the amount of transactions for the taking or transfer of savings in the bank that require the permission of the spouse. The bank authorizes the husband and wife to pour their wishes on deposits which are mutual property in the form of such written statement as long as it is not contradictory to the law and morals, other than that the poured in the form of such statements shall be made at the time of the account creation. ${ }^{15}$

According to Asdar, a written statement made by a depositary customer with his/her spouse concerning deposits in a bank which is a joint treasure should not be made in authentic form, simply signed by the husband and wife on a stamped paper. With this statement, in the case of withdrawal or withdrawal of deposits in the bank in accordance with the contents of the agreement made husband and wife required signatures from depositors and their husbands/wives. of course, the taking or transfer referred to in the statement is the taking or transfer done at the bank teller, because for the taking or transfer by using automated teller machine or other electronic equipment is given entirely to the registered party in the account, because the debit card for the individual account only provided for one person only. ${ }^{16}$

According Nursidik, other protection that can be given by the bank regarding deposits which is a joint treasure is the creation of a joint account. This joint account can be an option by a spouse who wants to control all forms of deeds committed by his/her partner in relation to deposits that are joint treasures in the bank. A joint account is an account owned by more than one person. The procedure for creating a joint account is similar to the individual account creation procedure in general, only in this case each party must fill out the account opening form and the difference will be on the signature sample card sheet, where every account owner must be signed. ${ }^{17}$ According to Customer Service of Bank Mega Makassar Branch, this joint account or individual join account is divided into two types, namely joint account or join account of individual persons and joint account or join account of legal entity. If a

\footnotetext{
12 Sonny Dewi Judiasih. 2015. Harta Benda Perkawinan. Kajian Terhadap Kesetaraan Hak dan Kedudukan Suami dan Isteri Atas Kepemilikan Harta Dalam Perkawinan. PT. Refika Aditama. Bandung. p. 19.

${ }^{13}$ Results of Interview with Customer Service of Bank Rakyat Indonesia on March 17, 2018.

14 Interview with Muhammad Auliyah as staff of Legal Bank Rakyat Indonesia Makassar Branch on March 10, 2018.

15 Interview with Muhammad Auliyah as staff of Legal Bank Rakyat Indonesia Makassar Branch on March 10, 2018.

${ }^{16}$ Interview with Asdar as staff of Legal Bank Tabungan Negara Branch Makassar on March 18, 2018.

${ }^{17}$ Results of interview with Nursidik as Legal staff of Bank Mega Makassar Branch on March 10, 2018.
} 
husband and wife want to create a joint account or join an account then they can create a joint account or join an individual account.

According to me as a writer, until now there is no protection that really given to the husband/wife depositing customers who are the joint treasure of the banks. Protection to the husband/wife of the depositor may be granted at the wishes of the customer and his/her spouse eg in the case of making a written statement concerning the procedure of withdrawal or transfer of savings which is a joint account, but in this case the bank never recommends her married client to make a written statement concerning the procedure for withdrawal or transfer of deposits which is a joint treasure joint account creation.

According to Ahmad Murad, until now the Financial Services Authority has not made a regulation to provide protection to the husband/wife of depositors because the authority on the procedure of withdrawal or transfer of deposits in the bank is given entirely to each bank. According to Ahmad Murad, one way that can be done by the husband/wife of the customer to control the deposits on behalf of his partner is by way of opening a joint account, in addition if the husband/wife depositors feel disadvantaged because in the withdrawal or transfer of bank deposits which doesn't seek approval from him and because of that the husband/wife of the customer feels aggrieved, the Financial Services Authority is willing to accept the complaint from the client's husband/wife and is willing to provide facilities to the husbands/wives of bank customers who feel aggrieved to settle the matter. ${ }^{18}$

In the case of deposit arrangements in banks that are mutual property, according to the authors should the bank make a regulation that also pay attention and protect the rights of the husband/wife customers. Similarly, a credit application procedure requiring the consent of a spouse should be in the case of withdrawal or transfer of savings which is a joint treasure also required by the husband/wife. In this case, the bank should make a rule that in the amount or limitation of certain withdrawals or transfers of a married customer and no agreement of separation of property with his spouse must obtain the consent of his spouse.

According to Yahya Harahap, the provisions of Article 36 Paragraph (1) of the Marriage Law which stipulates that in relation to joint property of husband and wife may act on the agreement of both parties, this is not so rigid as to mean the agreement of both parties in the use of common property is not absolutely applicable in all. This is because if any use of joint property required approval of both parties it will bring disaster to the life of the household. According to him for the expenditure of everyday needs such as buying clothes, shoes and food then the husband can act without the consent of the wife or husband. Thus the objective measure in this case is as long as the action is for daily purposes that are routine and customary then no agreement is required by both parties, except in the case of buying luxurious goods and out of everyday interest, the provisions of Article 36 paragraph (1) The Marriage Act must be fulfilled. ${ }^{19}$

Referring to the opinion of Yahya Harahap, the bank in this case can make a rule where in the withdrawal or transfer of savings for a certain amount which according to banking notion including transactions in large enough quantities then the banks should meet the provisions of Article 36 paragraph (1) Law This marriage involves obtaining the consent of the spouses of the client, although in this case the account is only in the name of the spouse only, but in the provisions of Article 1 letter $\mathrm{f}$ of the Compilation of Islamic Law it is determined that the property acquired either individually or jointly husband and wife as long as the marriage bond takes place next is a common treasure, without questioning being registered on behalf of anyone.

According to Muhammad auliyah and Asdar, transactions that can be categorized as large transactions in banks are transactions above Rp. 100.000 .000 (one hundred million rupiah), ${ }^{20}$ therefore according to the author should all transactions of withdrawal or transfer of savings made by depositors in the amount of transaction Rp. 100.000 .000 (one hundred million rupiah) required approval of husband/wife of married customers, because the transaction in the amount of Rp. 100.000.000 (one hundred million rupiah) up is considered a large number of transactions. In the transaction Rp. 100.000.000 (one hundred million rupiah) to the bank also always asks the source and purpose of the

${ }^{18}$ Interview Result With Ahmad Murad As Deputy Director of Strategic Management and Partnership of Local Government, Financial Services Authority of South Sulawesi Province On April 10, 2018.

${ }^{19}$ M. Yahya Harahap .1975. Hukum Perkawinan Nasional. C.V Zahir : Medan. P. 123.

${ }^{20}$ Interview with Muhammad Auliyah as legal staff of Bank Rakyat Indonesia Makassar Branch and Interview with Asdar as legal staff of Bank Tabungan Negara. 
use of funds and report to the transaction to the reporting center and financial transaction analysis, so according to the author should the bank also requested the consent of the spouse/depositors in the case of withdrawal or deposits for transactions above Rp100,000,000 (one hundred million rupiah) upwards as they are considered to be large transactions. In addition, transactions in the amount of Rp100.000.000 (one hundred million rupiah) upward can also be done only through bank tellers and can't be done through ATM, so it will facilitate the bank to ask for approval from the husband/customer's partner.

In my opinion as a writer, for transactions under Rp100.000.000 (one hundred million rupiah), the bank may use the Short Message Service Banking facility to notify the customer's husband/wife regarding the withdrawal or transfer of savings made by the customer, in the sense that the bank only just to notify the husband/wife of the customer and don't need to ask for his consent, so that all transactions made by depositors against the savings which is a joint treasure in the bank can be known by his/her spouse as the party who is also entitled to the deposit. So, at the time of account creation, the bank should not only ask the name of the husband/wife of the customer, but also ask the mobile phone number of the husband/wife of the customer to be used in the SMS Banking facility, so it can notify all transactions made by the account holder of the savings which constitutes joint property through SMS Banking notification.

In my opinion as a writer, the Financial Services Authority should also make a rule to protect the rights of the spouse's customer savings account, because within the provisions of Article 4 of the Law on the Financial Services Authority it is determined that the Financial Services Authority is established in order to activities within the financial services sector:

a. organized on a regular basis, fair, transparent and accountable

b. able to realize a sustainable and stable financial system; and

c. able to protect the interests of consumers and society.

Referring to the provision of Article 4 point c of the Financial Services Authority Act which stipulates that one of the objectives of the formation of the Financial Services Authority is to protect the interests of the public, therefore the Finance Service Authority should also protect the rights of the spouse's customer / together with making a rule to the banking party in order to have the consent of the spouse of the depository customer who is the security property in the case of the deposit or the transfer of the savings in a certain number of transactions and not only assume that the owner of the deposit in the bank is only recorded in the name accounts even though such deposits are common property.

\section{Conclusions:-}

The reason the bank didn't request the consent of the husband/wife of the depositing customer in the case of withdrawal/transfer of deposits which is a joint treasure in the bank is not in accordance with the provisions of Article 36 Paragraph (1) of the Marriage Law and Article 92 of the Compilation of Islamic Law which requires the existence of a husband consent and wife in the conduct of legal actions related to joint property, the reason the bank doesn't ask permission from the husband/wife of the depositing customer in the case of withdrawal or transfer of the savings on the grounds that the bank will find it difficult to determine whether the deposit is a common property or insufficient property, basically in accordance with the provisions of Article 5 of Bank Indonesia Regulation concerning Know Your Customer Principles, the bank is required to inquire about the source of funds from the deposits.

Basically there is no form of protection provided by the bank to the husbands or wives of depositors who are joint treasures in the bank, in which case the bank never requests the consent of the husband or the customer's wife in the case of withdrawal or transfer of deposits at the bank, but at the will of customers and their husbands/wives then they can create joint accounts but it can also make a written statement to make the withdrawal or transfer rules of savings which is the joint treasure. 


\section{References:-}

1. Abdulkadir Muhammad. 2004. Hukum dan Penelitian Hukum. Cet. 1. Bandung: PT. Citra Aditya Bakti.

2. Hermansyah. 2011. Hukum Perbankan Nasional Indonesia. Kencana Prenada Media Group : Jakarta.

3. M.Yahya Harahap .1975. Hukum Perkawinan Nasional. C.V Zahir : Medan.

4. Mustofa Hasan. 2011. Pengantar Hukum Keluarga. CV. Pusataka Setia:Bandung.

5. Sonny Dewi Judiasih. 2015. Harta Benda Perkawinan. Kajian Terhadap Kesetaraan Hak dan Kedudukan Suami dan Isteri Atas Kepemilikan Harta Dalam Perkawinan. PT. Refika Aditama. Bandung.

6. Zulkarnain Sitompul. 2002. Perlindungan Nasabah Bank: Suatu Gagasan Tentang Pendirian Lembaga Penjamin Simpanan Di Indonesia. Fakultas Hukum. Universitas Indonesia : Jakarta.

7. The Constitution of the Unitary State of the Republic of Indonesia 1945

8. Law Umber 1 of 1974 on Marriage.

9. Law Number 7 of 1992 concerning Banking as amended by Law Number 10 of 1998 concerning Amendment to Law Number 7 of 1992 concerning Banking.

10. Law Number 21 Year 2011 regarding the Financial Services Authority.

11. Compilation of Islamic Law 